\title{
HVMANITAS
}

\section{Ésquilo, Suplicantes um exercício de mestria cénica}

Autor(es): $\quad$ Silva, Maria de Fátima

Publicado por: Imprensa da Universidade de Coimbra

URL

persistente:

URl:http://hdl.handle.net/10316.2/27390

DOI:

DOI:http://dx.doi.org/10.14195/2183-1718_64_2

Accessed : $\quad$ 26-Apr-2023 11:01:57

A navegação consulta e descarregamento dos títulos inseridos nas Bibliotecas Digitais UC Digitalis, UC Pombalina e UC Impactum, pressupõem a aceitação plena e sem reservas dos Termos e Condições de Uso destas Bibliotecas Digitais, disponíveis em https://digitalis.uc.pt/pt-pt/termos.

Conforme exposto nos referidos Termos e Condições de Uso, o descarregamento de títulos de acesso restrito requer uma licença válida de autorização devendo o utilizador aceder ao(s) documento(s) a partir de um endereço de IP da instituição detentora da supramencionada licença.

Ao utilizador é apenas permitido o descarregamento para uso pessoal, pelo que o emprego do(s) título(s) descarregado(s) para outro fim, designadamente comercial, carece de autorização do respetivo autor ou editor da obra.

Na medida em que todas as obras da UC Digitalis se encontram protegidas pelo Código do Direito de Autor e Direitos Conexos e demais legislação aplicável, toda a cópia, parcial ou total, deste documento, nos casos em que é legalmente admitida, deverá conter ou fazer-se acompanhar por este aviso.

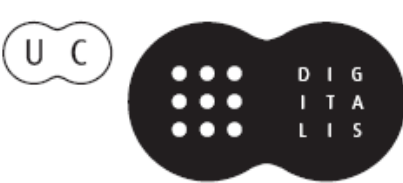


humanitas

\section{Vol. LXIV \\ 2012}

IMPRENSA DA UNIVERSIDADE DE COIMBRA

COIMBRA UNIVERSITY PRESS 


\title{
ÉSQUILO, SUPLICANTES UM EXERCÍCIO DE MESTRIA CÉNICA
}

\author{
Maria de Fátima Silva \\ Universidade de Coimbra
}

\section{Resumo}

Em Suplicantes, Ésquilo revela-se um profissional de teatro pleno; é patente no texto a visualização permanente que faz de cada motivo ou cena. E numa peça que obedece à convenção da súplica há motivos esperados: mulheres em fuga, perseguidas e em busca de um refúgio; a xenia da cidade que as acolhe; a imagem violenta do perseguidor.

Palavras-chave - encenação do medo, peças de súplica, bárbaro, coro.

\begin{abstract}
In his Suppliants, Aeschylus shows himself to be a real professional of the theatre; that he permanently visualizes each episode is clear from the text. In a play with a title such as this one, a number of motives are to be expected: persecuted women looking for a shelter, the xenia of a polis and the violent profile of a persecutor.
\end{abstract}

Keywords - fear on stage, suppliant plays, barbarians, chorus. 
Uma leitura minuciosa de Suplicantes revela como Ésquilo estava atento aos elementos de cena e, ao mesmo tempo, ao potencial do texto como um guião revelador das suas opções ${ }^{1}$. Dada a proveniência das Danaides, em fuga do Egipto e chegadas a território grego, o exótico tem um lugar relevante na caracterização imediata do coro, assente nos trajos e na cor da pele. Cena e auditório como que se tornam prolongamento uma do outro na recepção das estranhas visitantes. Desenhada a identidade do colectivo feminino em constantes alusões aos traços de caracterização mais evidentes, o movimento que se lhes impõe é fluido e variado, um factor tecnicamente apreciável numa peça de acção reduzida. Cabe, portanto, à potência coral compensar, de certa forma, as carências dinâmicas da intriga. Se as Danaides entram agitadas, temerosas, perseguidas, soltas de gestos de dor, a conversão a que, como suplicantes, estão obrigadas força-as à imobilidade à sombra dos altares argivos. É aí, manietadas pela convenção da súplica, que uma nova vaga de terror as invade - quando a aproximação do perseguidor se pressente -, agora expressa por uma paralisação impotente. Para, por fim, ser uma marcha ordenada aquela que acompanha a conversão de bárbaras em argivas e a assimilação de perseguidas como tranquilas cidadãs de uma comunidade grega a que afinal, por ascendente, pertencem. Os perseguidores seguem um ritmo inverso; de resto, a sua vinda é cuidadosamente preparada e antecipada pelo próprio pavor das suas vítimas; chegam por fim numa atitude calma, que se percebe à distância, desembarcam com movimentos moderados e correctos, até investirem, como previsto, contra a imobilidade feminina com gestos de uma violência enérgica. No geral, há na peça dinâmicas de cena - $\mathrm{o}$ ataque de um perseguidor contra a paz de uma cidade, ou a fuga de que Io, a antepassada das Danaides, se torna paradigma e que agora é replicada pelas suas 50 descendentes - que recomendam uma abordagem comparativa com outras soluções encontradas por Ésquilo para contextos similares, nomeadamente em Sete contra Tebas e Prometeu.

Como parece de regra nas peças de súplica, é à entrada das próprias suplicantes que se dá primazia. Além da prioridade, a caracterização do

1 A. Kavoulaki, 'Choral self-awareness: on the introductory anapaests of Aeschylus' Supplices', in L. Athanassaki, E. Bowie (eds.), Archaic and classical choral song, Berlin / Boston, 2011, 378 chama a atenção para a linguagem do coro, sobretudo nos anapestos iniciais (1-39), onde 'praticamente cada frase sublinha e aponta para um modo de agir; ou seja, a estrutura verbal combina pronomes deícticos da primeira pessoa, com verbos claramente performativos'. Assim - continua a autora, 381 -, os níveis narrativo e performativo tornam-se coesos e colaborantes. 
coro merece ao poeta uma atenção insistente. Afinal são estas mulheres que centram tudo o que na peça é acção e emoção, é a sua sorte o que está em causa. A que se junta um outro argumento igualmente poderoso do ponto de vista da técnica dramática: Suplicantes são a criação de Ésquilo em que à intervenção coral é dado um espaço maior. No que à sua identidade se refere, é importante a marca de um bando egípcio, quando o fluir da intriga se encarregará de proceder à metamorfose das que se apresentam como filhas do Nilo; afinal, por trás de uma aparência enganadora, estão mulheres que reivindicam um ascendente argivo e que se verão reintegradas no seu ambiente natural, a Grécia, em contraposição com a metamorfose que converteu Io, a sua antepassada, de filha do soberano de Argos em bovino, antes de a encaminhar para as terras longínquas do Egipto. Como às portas de Tebas, em Sete, à entrada de Argos não está um inimigo estranho, cuja presença põe em perigo a cidade; a distância aparente irá sendo reduzida por um esclarecimento progressivo, que revela a consanguinidade das duas partes em confronto.

Do país de onde provêm, um espaço que o horizonte da cena não contempla, falam as menções daquele que sempre foi o ex libris do Egipto, o Nilo, em termos convencionais. Esse é um cenário que as mulheres tornam presente desde as primeiras palavras que pronunciam (4-5), na referência às

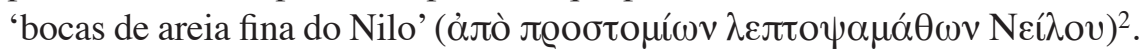
Confundido com o próprio curso do rio está o Egipto $(281,308)$, 'terra de brumas' (75), 'território abençoado por Zeus, onde nascem todos os frutos, um prado que o degelo fertiliza (...) e a água, imune às doenças, do Nilo' $(558-561)^{3}$.

Numa visão de sentido ‘ecológico', é desse contexto geográfico, como sua moldura natural, que os traços físicos e culturais das Danaides ganham

2 É dentro da mesma convenção que Helena, na peça euripidiana a que deu título, se refere, para identificar o território longínquo em que se encontra, às 'correntes do Nilo

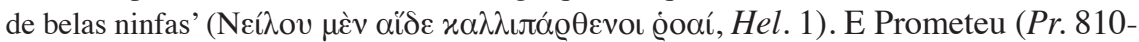
812), ao traçar a errância de Io a caminho do Egipto, define-lhe, como referência da proximidade de um destino, 'as quedas, o ponto em que, das alturas do monte

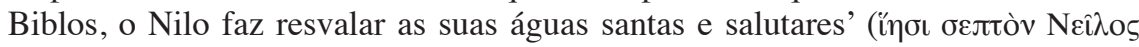

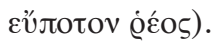

3 Era claro para os Gregos que a fertilidade do Egipto dependia das cheias do Nilo, por sua vez provocadas pelo degelo das neves da Etiópia. Sobre o sentido controverso deste passo, vide H. F. Johansen, E. W. Whittle, Aeschylus. The Suppliants. II, Nordisk Forlag, 1980, 440-448. 
justificação. É verdade que o seu aspecto e atitudes podem criar dúvidas ${ }^{4}$ e colocar, em alternativa, como prováveis diferentes origens. O ritmo do seu

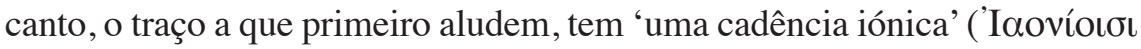
vó oı, 68$)$, de uma exuberância bárbara, feita de gritos agudos, lágrimas e brados fúnebres, expressivos de pavor; em terra grega, este canto parece

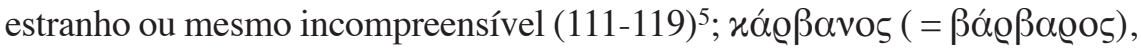
usado para exprimir essa diferença cultural, é uma palavra egípcia $(118,129$, $914)^{6}$, como outras palavras que contribuem para igual tonalidade: $\beta \hat{\alpha} \varrho ı \varsigma$ (836, 873; cf. Hdt. 2. 41. 4-5, 60. 1-2, 96. 5), usada pelo Arauto egípcio para definir o barco em que viajavam os perseguidores; ou ßov̂vı $\varsigma$, a pátria de Io, antepassada das Danaides metamorfoseada em bovino $(117,129,776)$. Johansen e Whittle 1980: 106, a propósito da linguagem das Danaides, sublinham a intenção de Ésquilo de lhe dar uma tonalidade estranha, apesar de, em geral, falarem grego. De acordo com estes comentadores, o objectivo desta sugestão é salientar a diferença entre Gregos e Bárbaros, ou o isolamento das estrangeiras em terra helénica. Dá portanto, em termos de estranheza, uma colaboração eficaz ao efeito da caracterização exterior.

Por seu lado o tom da pele, que as mulheres ferem numa manifestação

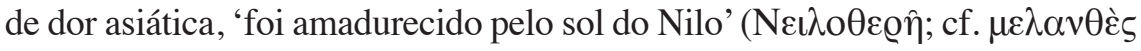

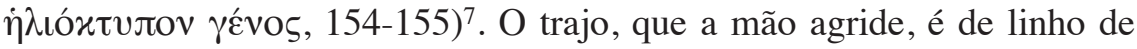

4 A surpresa e atenção que o aspecto estranho das Danaides provoca em Pelasgo replica o susto causado outrora pelo aspecto híbrido de Io, quando chegava ao Egipto (565-570).

5 Sobre a dificuldade na leitura e interpretação deste passo, vide Johansen e Whittle 1980: 65-67. Apesar da aparente disparidade entre a origem egípcia das mulheres e o seu canto ‘de ritmo iónico', talvez a própria hesitação de Pelasgo sobre a paisagem em que as enquadrar - africana ou asiática - possa ser de alguma justificação. Há que considerar, de resto, que sendo o Egipto, no tempo de Ésquilo, parte do império persa, podia incluir-se no mundo 'oriental'.

6 E. Hall, Inventing the barbarian, Oxford, 1989, 118, relata a polémica suscitada por esta palavra: enquanto, para alguns, se trata de um termo raro, egípcio ou hebraico, destinado a acentuar o tom estrangeiro aos ouvidos do público, Hall chama a atenção para o uso que dele é feito por falantes gregos (Supp. 914, Ag. 1061). Vide ainda F. R. Adrados,

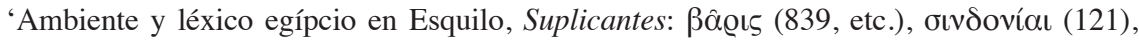

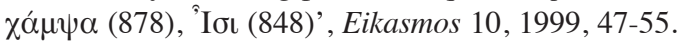

7 É em termos semelhantes que Prometeu alude ao Egipto, o destino último da errância de Io (Pr. 807-809): 'Vais chegar a um país distante ( povo negro ( $x \varepsilon \lambda \alpha \iota v o ̀ v ~ \phi v \hat{\jmath o v})$, residente perto da nascente do sol, junto do rio Etíops'. É de Épafo, o filho que Io concebeu de Zeus, nascido e criado junto do Nilo, e por isso negro (Pr. 851-852), que teve origem toda uma descendência de pele escura, apesar de proveniente de Argos. A importância da ambiguidade de origem de que, em última análise, depende 
Sídon (119-121) $)^{8}$, cintado de fitas $(457)^{9}$ e trabalhado com requinte (903). São de um grego os olhos de Pelasgo, porta-voz de dúvidas que decerto a audiência partilha; que se trata de 'não gregas' ( $\alpha v \varepsilon \lambda \lambda \eta v o ́ \sigma \tau o \lambda o v, 234)$ é o que os seus vestidos e fitas bárbaros denunciam, dentro de um modelo que a mulher helénica, independentemente da região onde habite, não reconhece como seu $(236-237,246)^{10}$. Numa referência que combina a geografia física de um espaço com os homens que o habitam - "não são iguais os traços de que nos dotou a natureza. Não é igual à do Ínaco a raça que o Nilo alimenta', 496-497 -, o coro sublinha o contraste que se cava entre filhos de diferentes paisagens. Sob a designação de 'bárbaras', o rei argivo procura nelas a especificidade de uma origem (279-289). O aspecto das mulheres aponta, de forma geral, para oriente. São sobretudo de Líbias ou de Egípcias os traços mais marcados; mas Chipre ${ }^{11}$, as mulheres nómadas da Índia ou as Amazonas são ainda hipóteses possíveis para a identificação das estranhas visitantes. Estes são sinais suficientes para estabelecer distâncias, que

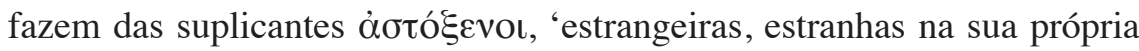
cidade' $(356)^{12}$. Por isso, as Egípcias têm consciência da hostilidade que

o destino das Danaides e o seu acolhimento em Argos parece exigir uma caracterização correspondente. Em cena, o tom escuro dos rostos há-de ser assegurado por máscaras que repercutem o efeito das palavras. Sobre a representação do 'negro' no teatro e na cerâmica grega, vide Hall 1989: 139-143.

8 Cf. Pers. 125, 537-538, 835-836. O linho era muito associado com as vestes egípcias (cf. Hdt. 2. 37. 2-3), como também de Persas e Iónios; representava qualidade e estatuto social. Por isso o contraste entre a qualidade da veste e o seu despedaçar lutuoso é impressiva. Os Fenícios, conhecidos como fabricantes e negociantes activos de tecidos de qualidade, superlativizam a excelência das vestes do coro.

9 No que parece uma sugestão interessante para um efeito cénico, as mulheres ameaçam de suicídio, caso não encontrem, no soberano argivo, protecção. No que não passa de uma hipótese sem concretização, antes funciona como uma forma de pressão sobre Pelasgo, elas admitem vir a usar as fitas do vestido como forca (459-467), uma mechane promissora, que explicam, em detalhe, a um interlocutor surpreendido. Do que é uma imagem de fraqueza provém a força persuasiva das suplicantes.

10 Hall 1989: 128 distingue $\chi \lambda \iota \delta \eta ́$, 'luxo', como a referência que se torna convencional no desenho do 'requinte bárbaro' na tragédia. Em contrapartida a lã, produto mais modesto, era o material de que as mulheres gregas confeccionavam o vestuário.

11 Hall 1989: 169 sublinha a estranheza de Chipre ser aqui integrado no mundo bárbaro e justifica esta perspectiva pela grande comunidade fenícia que habitava a ilha.

12 Aotó $\xi \varepsilon v o$, de acordo com o comentário do schol. ad loc., refere-se a quem 'agora é estrangeiro, mas antes estava ligado à cidade'. E é essa a melhor legenda para a origem ambígua das Danaides. 
a sua condição pode suscitar (973-974, 994-995), se for o seu aspecto de estrangeiras, meramente superficial de resto, a impor-se.

Feita a caracterização exterior das Danaides, Ésquilo imprime-lhes uma movimentação que segue uma curva feliz: primeiro é o pavor que justifica a agitação da vinda ${ }^{13}$; para Taplin ${ }^{14}$, está fora de dúvida o efeito da abertura, a entrada das Danaides, sujeita a uma coreografia que lhes reflicta 'o voo e o desejo de segurança'. Esse é o quadro de fuga de um perseguidor apenas previsível, mas por enquanto ainda ausente. A expressão eficaz do medo em cena mobiliza recursos de atitude e de palavra. A própria iminência do perigo, ainda não palpável, é o melhor estímulo a uma entrada emotiva ${ }^{15}$. Neste contexto de pavor, o coro não perde, mesmo assim, o sentido de coesão de um colectivo. $\Sigma \tau$ ó̀os $(2,29,234,461,933,944,1031)$, referido a um 'grupo coeso, participante numa expedição com um objectivo determinado', como a palavra que, desde o início, as Danaides se aplicam, tem, no contexto dramático, uma sugestão a reter ${ }^{16}$. Na coreografia a que estão sujeitas tem

13 Com base nos vv. 975-979, gerou-se a discussão a propósito da possibilidade de um grupo de servas acompanhar as Danaides desde a sua entrada em cena. O. Taplin, The stagecraft of Aeschylus, Oxford, 1977, 230-238 discute minuciosamente esta questão. As opiniões dos comentadores oscilam entre as que lhes dão um papel relevante sobretudo no canto final e as que as mantêm meramente decorativas. Taplin põe em causa a obrigatoriedade da existência deste coro de servas. Vide ainda M. McCall, 'The secondary choruses in Aeschylus' Supplices', Classical Antiquity 9, 1976, 117-131, que comenta a improbabilidade de os coros secundários, em Suplicantes, serem, no seu máximo, três: o dos Egípcios que seguem o arauto, além de, no final, um de servas das filhas de Dânao ou um de soldados argivos. E também este autor apoia a hipótese de dois semicoros de Danaides.

14 Taplin 1977: 193.

15 Ésquilo é senhor de uma mestria inegável no retrato cénico desta situação: o medo ou a fúria femininos, causados por um perigo apenas perceptível à distância, que produz movimentos anárquicos e de grande vigor emotivo. Este é o caso do célebre coro de Tebanas em Sete contra Tebas, ou das Erínias, as perseguidoras incansáveis dos criminosos que fazem uma entrada aparatosa em Euménides.

16 Johansen e Whittle 1980: 7 informam de que este termo é praticamente reservado, na peça, ao grupo de mulheres (e apenas uma vez aplicado aos seus perseguidores) e consideram-no portador de um sentido irónico quando aplicado às Danaides. Eu prefiro, no entanto, aceitá-lo como sugestivo de uma coesão de movimento e expressão, para além do que é a natural anarquia da fuga. Th. G. Rosenmeyer, The art of Aeschylus, Berkeley, Los Angeles, London, 1982, 33 sublinha, por sua vez, que o recitativo marca um ritmo regular, que acompanha a acomodação do coro junto aos altares, e que esta é uma atitude que sobretudo promove uma nota de calma. Kavoulaki 2011: 378-379, por fim, concilia as duas versões: o alinhamento do coro para a execução da 'marcha anapéstica' resulta de 
de haver organização e simetria. O movimento a que a situação de fugitivas as condena exige, mesmo assim, uma agilidade emotiva; $\phi \varepsilon u ́ \gamma \varepsilon \iota v ~(6,15)$ é, na sua boca, um brado de comando e o grito de um rasgar de alma (cf. Th. 78: 'este é o brado do meu medo'); a fuga significa um impulso, que não equivale a exílio nem à pena para um crime cometido, mas a algo mais profundo, a uma espécie de distanciamento de si mesmas e de aversão aos

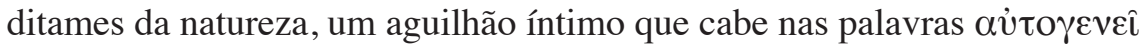

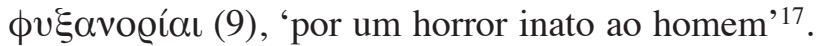

A previsão que Prometeu (Pr. 853-856) faz da vinda das Danaides a uma Io em fuga que tem por última etapa o Egipto - 'cinco gerações mais tarde, cinquenta donzelas, a sua descendência, hão-de voltar a Argos, mesmo contra vontade, para escapar a uma união com a sua raça, na pessoa dos seus primos' -, contém um roteiro para a acção de Suplicantes (cf. Supp. 329-331) ${ }^{18}$. Ao mesmo tempo impõe-se a convenção para um certo padrão de história: a vinda de fugitivas, a figura de um protector, a chegada dos perseguidores, a intervenção salvadora e a segurança enfim conseguida. À profecia subjazem indicadores de superfície: em primeiro lugar a perseguição de mulheres indefesas, que irão fazer, por força de uma vontade que as transcende, o caminho de regresso à pátria de origem. Com esse retorno, fecham um círculo genético e, ao mesmo tempo, uma primeira etapa na acção da trilogia. E para que o arco de vida se cumpra, as 50 Danaides replicam, agora em múltiplo, o destino e os motivos da sua antepassada,

um arranjo posterior a uma entrada emotiva e anárquica. De resto essa ordem entretanto estabelecida serve o tom ritualístico do párodo.

17 Johansen e Whittle 1980: 13-15 sintetizam as diversas interpretações a que esta expressão foi sujeita. Em primeiro lugar, as Danaides podem estar a referir-se a um horror

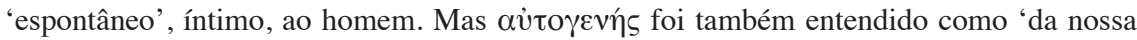
raça', o que circunscreve o âmbito dessa rejeição. Ou seja, a expressão serve a ambiguidade de toda a peça.

18 Considerada primeiro a mais antiga das tragédias conservadas, em função das suas características arcaizantes, como seja o predomínio da intervenção coral, Suplicantes foi depois situada em ano posterior, entre 467-459 a. C., ou seja, num período próximo da produção da Oresteia e do Prometeu. Vide R. S. Caldwell, 'The psychology of Aeschylus' Supplices', Arethusa 7. 1, 1974, 45; Taplin 1977: 194-198; H. Lloyd-Jones, 'The Suppliants of Aeschylus', in E. Segal (ed.), Oxford Readings in Greek Tragedy, Oxford, reimpr. 1991, 42-56. Em consequência, a predominância do coro deixa de ser ditada por um padrão dramático em vigor numa fase muito antiga da tragédia, para ser entendida como uma opção do poeta. 
também elas recusando um amor que lhes repugna. Io é, portanto, na acção de Suplicantes, uma referência e um modelo dramático incontornável.

Desse ascendente, as Danaides deixam o pressuposto nas primeiras palavras que proferem (16-19) ${ }^{19}$. O destino que agora buscam como um refúgio, de que as separava a enormidade do mar, é a Argólida, a origem da sua raça, a terra desde sempre ligada a Io. Entre esses que são os dois pólos de uma genealogia, as Danaides inserem as etapas intermédias, Épafo em primeiro lugar, o fruto da união da sua antepassada com Zeus; com o seu toque divino - para sempre consagrado no nome de Épafo, 'o toque' -, o deus supremo pôs fim à fuga e instalou a tranquilidade, fazendo suceder à violência a pacificação $\left(41-46,311-314,535 ; \operatorname{Pr}\right.$. 849) ${ }^{20}$. Recordar este passado distante, com uma idade medida em cinco gerações, é mais do que trazer o mito à memória dramática e assim alargar os limites da acção; é também justificar a construção cénica com opções de uma simetria desejada com este passado. Os nomes de Io e de Épafo são uma espécie de senha, que permitirá às suas descendentes repor uma acção: num lugar determinado - o mesmo onde toda a saga teve início -, com um tom equivalente - o de um mesmo sofrimento -, e com igual surpresa - a mesma que ditou o rapto da amada de Zeus e que agora traz de volta, 'de modo inesperado', a sua descendência (48-55).

$\mathrm{O}$ que o párodo, em tom lírico, estabeleceu como expectativa e justificação da vinda das Danaides é retomado, com maior racionalidade e clareza, na esticomitia que as mulheres travam com o soberano argivo. Num diálogo que o coro conduz, com perguntas que são um apelo à memória e a uma espécie de percurso de anagnorisis - onde o conhecimento que demonstram desse passado é o testemunho da sua identidade -, a história de Io recua à sua origem: a de sacerdotisa do templo de Hera argiva (291-292),

19 Os primeiros versos de apresentação dão lugar a uma prece; Rosenmeyer 1982: 154 considera este o tom adequado à abertura desta peça como ao sentido global da trilogia e pode, por isso, afirmar: 'A prece funciona assim como o núcleo, a força propulsora de toda a acção dramática'.

20 Depois de se deter nos pormenores da fuga de Io e do nascimento de Épafo, ou seja, nas etapas que encarnam a passagem da crise à pacificação na origem da linhagem argiva, Ésquilo passa rapidamente sobre as gerações intermédias da família - Líbia e Beto -, até chegar a Dânao e Egipto, pai e tio das Danaides; com eles reinstala-se a intranquilidade e a perseguição, que só o regresso ao solo pátrio tende a pacificar. É portanto sobre os extremos simétricos do arco geracional que o poeta se detém. Hall 1989: 36 lembra como a este mito argivo andou ligada a origem de um grande número de povos (Egípcios, Árabes, Fenícios e Líbios), 'fazendo de Argos o centro de uma enorme genealogia internacional'. 
por quem Zeus alimentou um amor, neste caso incompatível em função de

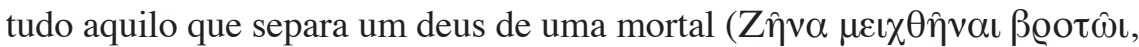
$295)^{21}$. Por ciúme, Hera puniu a rival com a terrível metamorfose em vaca, que um moscardo, como aguilhão penetrante, impelia sem cessar em doloroso calvário (306-308). Com a equivalência do nome grego do moscardo, $\mu$ í $\omega \pi \alpha$

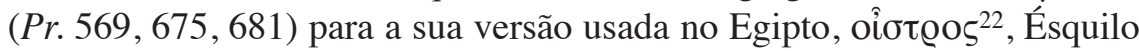
dá ao insecto, como arma de interferência superior da divindade, o valor de um passaporte, que permite e legitima a transferência entre duas paisagens e, ao mesmo tempo, a confluência de duas naturezas e culturas.

Está aberto o caminho àquele que sempre foi o traço caracterizador de Io, a fuga tresloucada, um elemento que se repercute na exuberância da cena, ao mesmo tempo que justifica longas rheseis descritivas de um itinerário mais ou menos exótico. A imagem de uma jovem metamorfoseada em vaca, que pastava flores (44-45, 538-540) quando foi surpreendida por um raptor divino, corresponde a uma convenção, que Eurípides repete com frequência ${ }^{23}$. Ameaçada pelo aguilhão do moscardo, Io põe-se em fuga.

O medo, materializado no moscardo, é o que lhe comanda a corrida (Pr. 568, 580, 882); a errância prolongada a que se vê sujeita é, por seu lado, a imagem de um destino. Para Io, Ésquilo prefere a família semântica

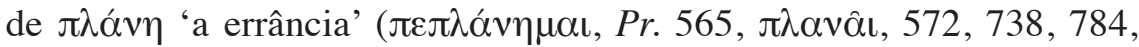

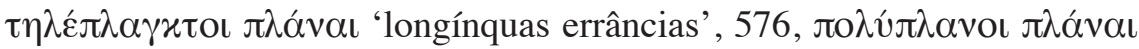

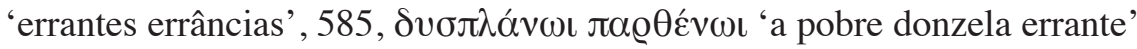

21 Tal como no Prometeu, a razão da errância de Io oscila entre dois motivos fundamentais: a incompatibilidade que separa deuses de mortais (cf. Pr. 737-738), ou os ciúmes de Hera (Supp. 295-299, Pr. 590-592, 601-602), a esposa legítima, ofendida e, por isso, responsável pela perseguição da rival. Na realidade ambas as palavras, ol̂otoos e $\mu v ́ \omega \psi$, são designações aplicáveis ao moscardo. A primeira, no entanto, usou-se também para a 'loucura' humana (cf. E. Hipp. 1300). Esta duplicidade de sentido é funcional neste episódio de Io. Vide M. Griffith, Aeschylus. Prometheus Bound, Cambridge, 1983, 195. Por seu lado, J. de Romilly, La crainte et l'angoisse dans le théâtre d'Eschyle, Paris, 1971, 84, lembra o sentido duplo de oîot@os que refere, além do insecto, qualquer aguilhão e, nesse sentido mais amplo, reúne com ele a ideia de 'medo'.

22 Cf. Pr. 566, 580, 589, 675, 836, 879; no v. 580, Io faz a transposição metafórica

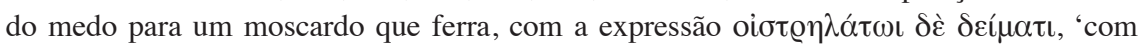
um medo que persegue como um moscardo'.

23 Esta é, já no mito, a ocupação natural das mulheres raptadas, como Perséfone e Europa. Eurípides dá-lhe tons exuberantes, quando descreve, no Íon 887-892, o rapto de Creúsa por Apolo, ou, na Hel. 243-247, o da rainha de Esparta por Hermes. Vide M. F. Silva, Ensaios sobre Eurípides, Lisboa, 2005, 330-332. 


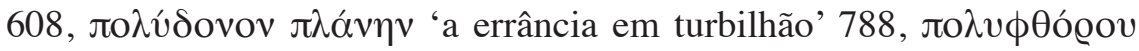

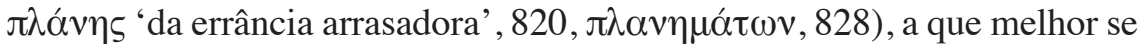
adequa a uma marcha de desfecho incerto, porque se trata, para a princesa argiva, de desviar-se de quem a persegue, por caminhos imprevisíveis, até um alvo ignorado. É a essa descoberta que a palavra profética de Prometeu dá um contributo decisivo (Pr. 700-741). 'E $\lambda \alpha u ́ v o \mu \alpha \iota$ 'ser conduzido' alude, por seu lado, à presença imperiosa do perseguidor (Pr. 682), e

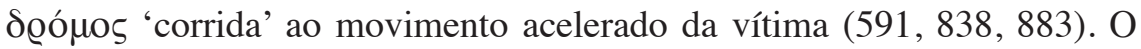
ritmo que exprime o seu constante deslizar pelos caminhos da descoberta, de si mesma e da vida que os deuses lhe destinaram, é também um retrato da loucura. A própria incoerência dos passos, a incerteza da rota, a busca inconsciente, a presença alucinante do divino, atormentam a jovem no trajecto que a arranca de uma existência tranquila de donzela (Pr. 647-654) para a consumação do seu destino de mulher, amante de Zeus, e sobretudo mãe de um filho e fundador de uma raça (848-852, cf. 1063-1068). É a metamorfose, física e mental, o que assinala, como um rito de passagem, a nova etapa de vida da filha de Ínaco; 'forma e razão alteram-se' ( $\mu$ o@фì

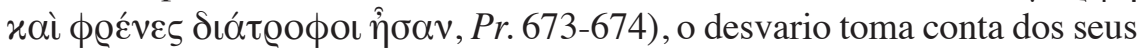

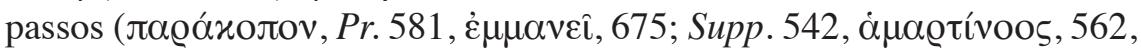
$\mu \alpha \iota v o ́ \mu \varepsilon v \alpha)$. E para que, à expressividade do texto, se some a exuberância da cena, as palavras juntam-se à acção quando Io, já de posse da profecia que passa a iluminar-lhe a rota, deixa Prometeu para prosseguir o seu caminho (Pr. 877-886). Como se atingida pela queimadura de um ferro em brasa, inesperada e profunda, Io é sacudida por um espasmo e um acesso de

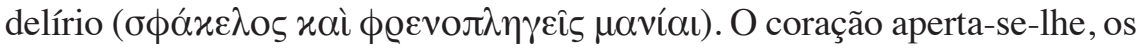
olhos revolvem-se, o movimento toma-lhe os membros, a língua entorpece, a razão escapa-se-lhe. Estas são as palavras que o poeta põe na boca do actor como uma poderosa indicação de cena.

É equivalente a experiência feminina que, cinco gerações mais tarde, se repete com as filhas de Dânao. Mas como se o fluir do tempo afastasse a descendência argiva da moldura sacra da sua origem, o mesmo quadro aparece agora humanizado ${ }^{24}$. A mesma exigência de vida e obediência a

24 Romilly 1971: 55-57 distingue exactamente, na cena esquiliana, o medo que tem uma causa 'precisa e material, que há todas as razões para se sentir iminente', daquele outro 'temor dos deuses, cuja acção se faz sentir directamente, ou sob a forma de um moscardo sobrenatural ou de génios vingativos'. Este último é sinal de uma sanção por um erro cometido. 
um propósito natural que as transcende - o casamento e a maternidade traduz-se, para as Danaides, em termos mais humanos, ainda que de uma ambiguidade polémica: em vez de um perseguidor divino, o próprio Zeus, que assediava a sua antepassada, é uma espécie de rejeição íntima, instintiva,

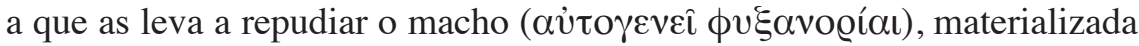
'na união com os filhos de Egipto e na sua demência sacrílega' (Supp. 9-10). Destas palavras resulta o insuperável desafio: como ler esta recusa? Como um desvio condenável que impede a consumação do que a condição feminina lhes impunha, casamento e maternidade? Como a repugnância legítima de uma união contra-natura porque consanguínea, ou anti-social porque inspirada pela violência? De Zeus, cujo nome abre a peça, agora invocado como deus dos suplicantes, se espera que, mais uma vez, com o seu toque divino, pacifique e reintegre as que são suas filhas.

É no momento em que, na descendência de Épafo, se atinge a geração de Dânao e Egipto (Supp. 320-323) que tem início a história das Danaides, como desfecho adiado do trajecto de Io. De novo a fuga e o exílio se instalam entre as sucessoras, femininas, de Ínaco, para que ocorra o caminho de regresso à Argos pátria. Ao invés de Io, porém, que fugia só, as Danaides beneficiam da condução prudente de seu pai. Dânao assume, na peça, a responsabilidade de conduzir cada passo do coro; foi ele que lhe incentivou a fuga e é ele que instrui as mulheres sobre o que fazer e o que dizer. Sem ele, as Danaides imobilizam-se e simplesmente aguardam (882-965). Dânao tem, portanto, um papel de condutor firme a representar.

$\mathrm{O}$ trajecto tem, desta vez, um alvo definido e programado - 'o regresso às costas de Argos, berço da nossa raça', 16 -, onde a Pelasgo, de certa forma substituindo-se a Zeus, caberá o 'toque' libertador, expresso numa xenia que põe fim à dor e pacifica. Mesmo assim, enquanto no plano humano as Danaides aguardam a decisão para que Pelasgo terá de obter a adesão do seu povo, é em Zeus que a sua expectativa se concentra (524-599), apelando a uma intervenção que repita aquela que o senhor supremo teve junto de Io. As condições novas deste exílio - a natureza humana do perseguidor, a fuga racional e decidida das mulheres, a nitidez do refúgio a atingir, a presença tutelar de Dânao - dão-lhe um tom mais moderado do que aquele a que se submeteu Io. Responde-se assim às condições diferentes de mobilização de um colectivo em cena, que age em conjunto em nome da salvação colectiva e dos meios para a atingir. A dúvida circunscreve-se agora ao acolhimento a esperar, colocando a súplica e a xenia como argumentos e valores prioritários. Como muito a propósito salienta Taplin 1977: 192, é 
'sobre a recepção de suplicantes em fuga por uma cidade ou governante modelo e a repulsa de perseguidores agressivos que a peça, no seu todo, se concentra'.

Mas, naturalmente, as novas condições do episódio não eliminam a emoção que, à sua medida, as Danaides repercutem do passado. 'Inexperientes

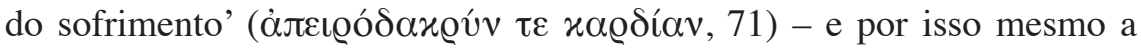
ele susceptíveis -, a dor e o medo (72-73) são ainda o grande estímulo da sua atitude. À corrida tresloucada substitui-se o canto fúnebre, como expressão do temor de que o socorro esperado falhe. O uso do refrão dá ao conjunto um tom litúrgico. Com exuberância, o coro entoa, com requintes orientais, um lamento, a homenagem antecipada a si mesmo (116): 'Em vida, celebro o meu próprio luto'. Gritos, soluços, lágrimas, o esfarrapar das vestes impõem em cena, por antecipação, um luto anunciado, mas ainda duvidoso. Tal como as Tebanas que registam a presença do inimigo contra uma fortaleza, qual navio sob os golpes da borrasca (Septem 113115), também as Danaides (Supp. 125-126, 134-136, 174-175) se tomam por navio exposto a um futuro incerto. Em ambos os casos, porém, o que atormenta estas mulheres é sobretudo a incerteza sobre o socorro, divino e humano, de que necessitam. E talvez até a extravagância da atitude que assumem seja desmesurada em proporção com o perigo real.

Como parece convenção das peças de súplica (principalmente se tivermos em conta o paralelo com Suplicantes de Eurípides), o movimento do coro segue um padrão comum: as mulheres chegam de fora a um outro território, instalam-se na periferia, num lugar sacro, até ao momento de, em boa ordem, enfim penetrarem no espaço cívico da polis de acolhimento. Depois de uma entrada que lhes acentua o aspecto estranho e exótico, a atitude de súplica que adoptam parece conformar-se aos hábitos gregos, um ponto de partida para a sua aproximação de Argos. Tal como as vestes e a cor da pele as caracterizam quanto à proveniência, os acessórios de que são portadoras identificam-nas como suplicantes (20-22): 'Que país mais favorável poderíamos nós abordar com estes braçados de suplicantes,

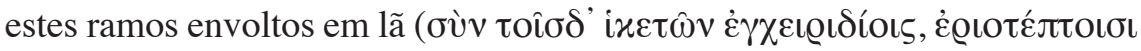

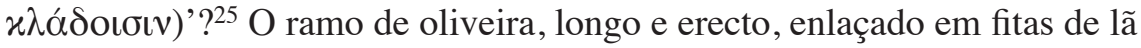

25 T. Gantz, 'Love and death in the Suppliants of Aeschylus', Phoenix 32, 1978,

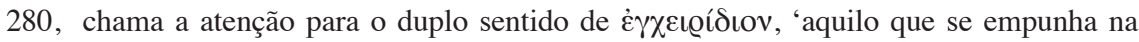
mão'; se a evidência o identifica com os ramos das suplicantes, a palavra tem também um relacionamento imediato com 'arma, punhal', a que muitas vezes se aplica. Assim, além 


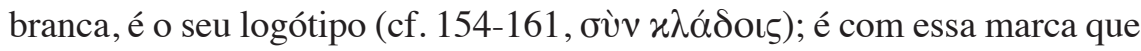
dirigem aos deuses os seus apelos, fazendo valer o estatuto que os ramos tornam evidente (28-30), e se acolhem à protecção dos altares (82-83) ${ }^{26}$. Os conselhos, dados por Dânao às filhas, sobre a atitude a adoptar são uma espécie de registo de direcção de cena, de que o público deve tirar também proveito. A imobilidade é uma receita prioritária: que se mantenham sentadas na colina sacra $\left(\pi \alpha ́\right.$ jos, 189) ${ }^{27}$, junto ao altar $(189,224)$, segurando no braço esquerdo ${ }^{28}$ os ramos como insígnia de súplica (191-193), de modo reverente. Tão importante quanto a atitude é a linguagem; o tom deve ser humilde, lamentoso e sofrido, tal como a expressão discreta e reservada. É importante esclarecer desde logo a inocência de qualquer crime (que poderia trazer poluição à cidade), saber preservar o sentido da oportunidade na intervenção e ser comedido nas palavras (194-203); esta é a fórmula conveniente a quem se encontra numa situação de desfavor, porque estrangeiro e vulnerável. Com esta atitude, aparentemente submissa, o coro exerce uma certa forma de poder e cria condições para ver realizado o seu objectivo: o de se acolher à protecção de Argos.

Que o conselho de Dânao é avisado (204) mostra-o a reacção do rei argivo, a quem a súplica é dirigida. Cumprido pelas Danaides o código que se impunha - 'os vossos ramos de suplicantes estão pousados como mandam as regras, aos pés dos deuses da cidade', 241-242; cf. 332-333, 345, 354-355 -, Pelasgo reconhece nelas, apesar de todos os outros indícios,

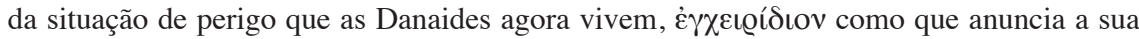
posição futura de assassinas dos primos, convertidos em maridos indesejados.

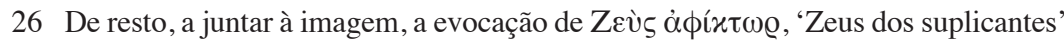
(1), que constitui as primeiras palavras do coro, sublinha a mesma evidência. Zeus, como progenitor do filho de Io, tem, no mito e na peça de Ésquilo, um papel destacado. É como protector das suplicantes que é, antes de mais, aqui invocado.

27 A inclinação do espaço a que as Danaides se acolhem proporciona o ponto de observação de onde Dânao pode perceber, à distância, a vinda de alguém. Aí se situam o altar e as estátuas dos deuses a que dirigem apelos. O primeiro deus a que o grupo de mulheres alude é Zeus (209), depois Apolo a quem os raios de sol identificam (212-214), logo Posídon, de tridente em punho (218), e, por fim, um Hermes 'à maneira grega' (220), além de outros referidos em conjunto (223). Os apontamentos breves que ajudam à caracterização de cada divindade são também a denúncia do esforço feito pelas estrangeiras no sentido de identificarem os sinais de um culto com que não estão familiarizadas. Este é o momento em que o canto ritual das Danaides estabelece com os deuses uma cumplicidade íntima.

28 Deixando assim liberta a mão direita para a estender a Pelasgo, de acordo com a etiqueta da súplica. 
mulheres gregas. No altar vê-as imóveis, de joelhos, em posição que exige respeito e impõe solidariedade (413-416). E o conselho que dá de que se exprimam de forma lacónica e directa não faz mais do que repetir o de Dânao (273-274). Por fim, em tom lírico, num kommos com o soberano, as Danaides dão voz à sua súplica (347 sqq.), sem preservarem todavia o laconismo que o sentido de oportunidade e a cultura do interlocutor recomendavam ${ }^{29}$. Tratava-se afinal, para Ésquilo, de estabelecer a problemática de fundo da peça.

Cabe a Pelasgo, desta vez, determinar o espectáculo que melhor pode persuadir o povo argivo, de modo a acrescentar o seu assentimento à pretensão das fugitivas. Como delegado dos interesses das filhas, Dânao deve, por ordem do rei, transferir para os altares da cidade o mesmo espectáculo. No teatro, como no quotidiano da polis, a imagem dos ramos, depositados junto aos altares, não deixa de suscitar compaixão (480-485).

Em contraposição com as fugitivas, a peça implica o efeito obtido pelos perseguidores. E também sob este aspecto a ambiguidade é um processo habilmente explorado e multiplicado. A antecipação - criada pela angústia das mulheres - e o falso alarme mantêm constante uma ameaça sempre latente, fazendo da chegada efectiva dos Egípcios o cume de um processo.

É já na párodo, enquadrada no pavor das fugitivas, que a primeira imagem dos perseguidores é adiantada (30-34): 'E antes que esse enxame de

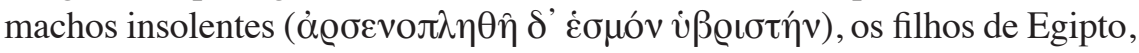
ponha os pés neste solo pantanoso, com o seu barco veloz, expulsem-no para o mar'. É visível, em imaginação, o número e a coesão com que se movimentam, a agressividade e a insolência que os determina, a chegada por mar e a abordagem em solo argivo. E o coro passa a concretizar a ameaça que 'o bando' representa (38-40): o assédio sexual que, do ponto de vista feminino, parece duplamente condenável, porque provém de parentes, 'os sobrinhos de seu pai', e porque indesejado pelas que se sentem suas vítimas. Esta é uma primeira metáfora de outras que se sucedem na peça, para retratar

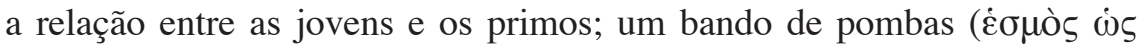

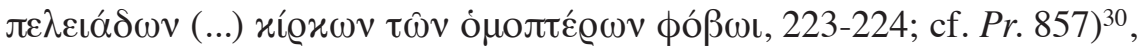

29 O próprio coro o reconhece (455): 'Escuta, dos muitos argumentos de súplica, este último'.

30 Pr. 854-859 repete exactamente o mesmo contexto, sublinhando a consanguinidade

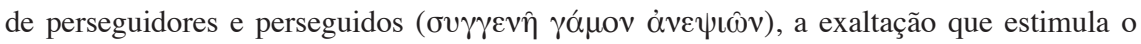
bando de perseguidores - falcões - contra pombas indefesas. 
perseguido por falcões, é uma imagem paralela, que mantém a semântica do número e da ferocidade animal; desta vez, o quadro completa-se com a oposição entre as duas partes, ambas numerosas, uma pacífica e a outra violenta; mas é sobretudo a consanguinidade o que aqui Dânao sublinha com mais força, perseguidor e vítimas ambos alados e do mesmo sangue

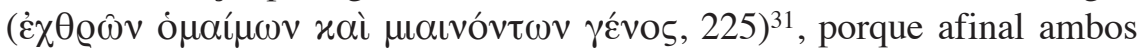

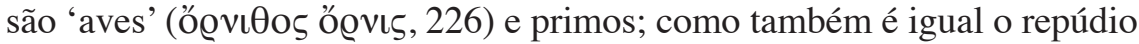
das Danaides, agora alargado ao que o próprio pai partilha (227-228). A metáfora animal regressa, encontrando (350) para o quadro semelhança com a novilha perseguida pelo lobo (cf. 642) e com a fragilidade feminina perante 'aves de rapina' e 'serpentes cruéis' (510-511) ${ }^{32}$.

Além da imagem metafórica da perseguição, um exercício de grande mestria poética ${ }^{33}$, a imaginação apavorada das Danaides antecipa, em traços nítidos, a arremetida dos filhos de Egipto. Como argumento para impressionar Pelasgo, no apelo que lhe é feito, as Danaides confrontam-no com um quadro de agressão ainda virtual, a antecipar o momento de violência efectiva que a chegada dos perseguidores virá a consumar (423-433, 882 sqq.): o rapto é ditado, antes de mais, no seu significado profundo, pela hybris masculina, de que cada passo ou gesto é a extensão visível; sem respeitarem os limites físicos do santuário, tutelado pelas estátuas dos deuses, os perseguidores virão destruir a imagem estática das suplicantes, arrastadas para longe dos altares e agarradas pelos vestidos.

Dânao, do seu ponto de observação, faz o papel de uma espécie de arauto ou mensageiro que vê à distância e adianta cada movimento de perigo (710 sqq. $)^{34}$. No que de certa forma se assemelha ao cruzamento

31 Com um oximoro feliz, Ésquilo valoriza o que no quadro é paradoxal: que o mesmo que os une, raça e consanguinidade, os torne inimigos e sugira poluição, quer se trate de pombas e falcões, quer das Danaides e dos primos.

32 A insolência dos filhos de Egipto produz ainda a sua comparação com corvos (751) e cães (758-761).

33 A este propósito afirma, com muita pertinência, J. de Romilly, La crainte et l'angoisse dans le théâtre d'Eschyle, Paris, 1971, 21: 'A descrição do medo em Ésquilo concilia dois traços que, noutros autores, poderiam excluir-se; é, ao mesmo tempo, realista e imagética, precisa e poética, exacta e metafórica'.

34 O papel que lhe é atribuído em Suplicantes coloca-o na posição inversa de Ínaco, em relação a Io (Pr. 655-671). De acordo com os oráculos, Ínaco expulsa de casa a filha, exila-a, entrega-a a uma errância solitária, pelo desconhecido, mesmo que contra vontade. Assim a culpa do destino da jovem é imputada por completo a Zeus. Em contrapartida, a situação de alguma dependência das Danaides em relação ao pai é justificada pelos atributos 
entre a descrição que o coro de Tebas faz, em Sete, de dentro das muralhas da cidade do avanço do invasor, e de uma teichoskopia, a narrativa de um exército inimigo que se vê do alto da muralha, de tradição homérica, o pai das Danaides observa e descreve sinais do avanço de um exército. O contexto é de dúvida. O pó, um mensageiro sem voz (180), é visível ao longe. Cortam-no, esses bem audíveis, os toques das siringes (181). Da nuvem indistinta da poeira vão-se projectando as tropas armadas de escudos e lanças, sobre cavalos e carros (182-183). Com agudeza, Dânao imagina, pelos próprios meios da arremetida, que se trata de um exército local, numa manobra de inspecção às recém-chegadas. No seu conjunto, esta intervenção de Dânao prepara a chegada do protector, a que não falta intensidade emotiva, já que a sorte das mulheres depende dele. Mas é também a antecipação de uma segunda entrada, ainda mais extensamente preparada, por se tratar, nesse caso, do inimigo. Em dúvida, neste momento, ficam apenas as intenções de quem chega. Para todas as eventualidades, Dânao recomenda a atitude mais correcta e, com as suas ordens, imobiliza o coro que então se assume na qualidade prevista de suplicantes.

Ultrapassada a hesitação do rei argivo, que, colocado num dilema entre o perigo da guerra e o respeito por Zeus dos Suplicantes, segue os ditames da piedade, a situação das mulheres muda. Primeiro Dânao afasta-se, sob escolta de um corpo de guarda local, para repetir, nos altares do círculo urbano, o gesto de súplica (492-496, 500-503) $)^{35}$, alargando a impressão causada, e o compromisso imposto, ao colectivo dos cidadãos. Este é o primeiro sinal evidente de uma ampliação de votos e de assumpção de responsabilidades, do chefe para o povo no seu todo.

Quando se ausenta aquele que, até ao momento, foi o condutor e instrutor das fugitivas, Pelasgo assume por solicitação das mulheres esse papel. É sob seu conselho que a posição do coro se altera (504-505), obediente ao que é uma clara indicação cénica. Ao abandonar, por sugestão de Pelasgo, os ramos de suplicantes e o lugar onde se encontrava, junto aos altares, o quadro ganha novo significado, concorrente, no dizer de Johansen e

de que elas o acham dotado, como conselheiro e condutor dos seus passos e palavras (11-12, 969-970). Sobre o sentido psicológico assinalado, por alguns comentadores, nesta relação, vide Caldwell 1974: 50-52.

35 O texto deixa, sobre a caracterização de Dânao, a sugestão de que talvez ela reproduzisse um marinheiro (503, cf. 177); algum traço exterior poderia assinalar essa qualidade, do mesmo modo que os ramos das mulheres identificavam, aos olhos de qualquer estranho, um suplicante. 
Whittle 1980: 393, com o do afastamento de Dânao em direcção à cidade: 'As Danaides aceitam colocar os seus ramos sobre os altares, um gesto que significa que a força da sua súplica se mantém, mas agora dirigida aos deuses e ao povo de Argos, e não directamente a Pelasgo'. Mas, do ponto de vista das Danaides, o afastamento deste lugar de protecção expõe-nas de novo, com mais vulnerabilidade, à perseguiçãa ${ }^{36}$. O tom emotivo cresce com este simples movimento; o contraste entre a segurança da autoridade masculina e o pavor que se vai apoderando das mulheres é cuidadosamente assinalado: medo ( $\phi o ́ \beta \omega \iota, \delta \varepsilon i ̂ \mu ', 513-514)$ o sentimento que domina as

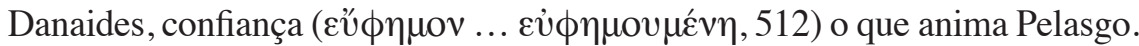
Este 'medo' e esta 'confiança' podem ter, nas circunstâncias, um sentido pregnante, condicionados não apenas pela ameaça, ainda longínqua, dos perseguidores, como pela imprevisibilidade, mais próxima, da decisão de Argos. Depois do afastamento de Dânao, sucede-se o do soberano argivo ${ }^{37}$. Sozinhas, é agora apenas nas preces que as mulheres encontram refúgio.

Essa solidão prolonga-se até ao regresso de Dânao, que vem lançar sobre o temor latente das filhas palavras de tranquilidade. No que toca aos Argivos, o compromisso de protecção foi assumido; consignado numa formalidade legal (609-614), o propósito do rei e do seu povo ganha um valor expresso e firme. Do ponto de vista dramático, esta decisão promete uma segurança final, que há-de ser certamente posta à prova pela concretização do perigo. Uma prece agora em favor da cidade generosa substitui 'medo' por 'confiança'. Tanto mais penetrante é o efeito de notícias que, embora esperadas, ganham neste contexto um efeito de surpresa. O Dânao que louva a sensatez e a propósito das preces das jovens é o mesmo que, restituído ao seu posto de observação, no momento seguinte lhes anuncia a chegada dos perseguidores (710-714). Esta nova aproximação corresponde a uma outra abordagem do perigo; Dânao, como antes, vê, do seu ponto de observação

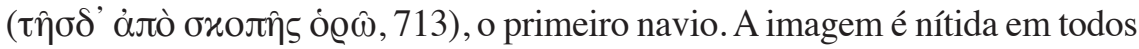

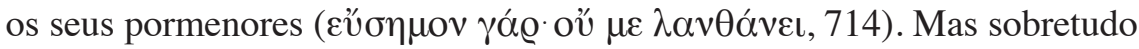

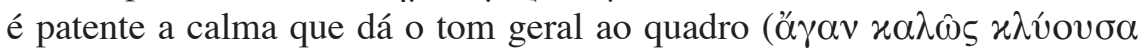

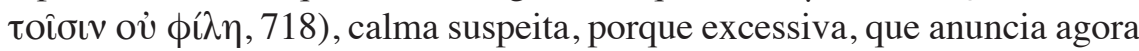
a vinda de um verdadeiro inimigo. O progresso da aproximação obedece

36 'A $\lambda \sigma o \varsigma$, um recinto sagrado para onde as Danaides se deslocam, não tem a mesma inviolabilidade de um altar.

37 É provavelmente também em obediência à convenção que o coro permanece em cena e não se afasta com Dânao ou Pelasgo. 
a uma estratégia plástica: do barco da frente, visível no pormenor, Dânao foca-se na tripulação, de que distingue o contraste entre o negro da pele e o branco das vestes; o parentesco entre os recém-chegados e as fugitivas fica patente. Por fim, já toda a frota e o total dos homens que a constituem se oferece à vista $(720-721)^{38}$. O ritmo aumenta, com o baixar das velas e o rumor dos remos, em movimentos certos e rápidos (724).

Completando a anterior recomendação de Pelasgo, Dânao sugere, a este coro vulnerável, tranquilidade e prudência (724), embora preveja a vinda próxima de um arauto, com intenções de rapto e violência (726-728). Confiança é ainda a palavra que se impõe, no socorro que não há-de faltar e na sacralidade do local em que se encontram. Nas suas palavras, Dânao mobiliza, para um agôn que se adivinha aguerrido, todas as forças da peça: de um lado, os perseguidores, representados pelo arauto, do outro, os protectores, Pelasgo e os Argivos; e, sobre todos, a mão tutelar dos deuses, a que as Danaides se abrigam. Em cena, um crescendo de acção e de emoção está prometido.

É num jogo alternante destes elementos que reside o clímax do movimento dramático. Primeiro o medo reapodera-se das mulheres, perante a iminência de um perigo, que deixa de ser previsível, para passar a anunciado e próximo. A agitação crescente impõe-se a um coro - o mesmo que antes fugia -, agora preso a um lugar. A expressão do medo obedece portanto a estéticas diversas, uma primeira dependente do movimento, a actual sobretudo das palavras ${ }^{39}$.

O tom da cena que se inicia é dado pelas próprias Danaides (734-735):

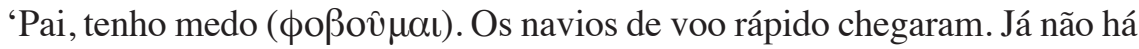
tempo de demora'. E logo, numa extensão mais emotiva, aprofundam o sen-

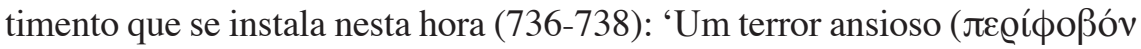

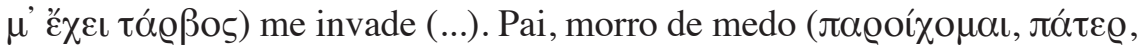
$\delta \varepsilon i ́(\alpha \tau \iota)$ '. Temores a que cabe agora a Dânao responder com palavras

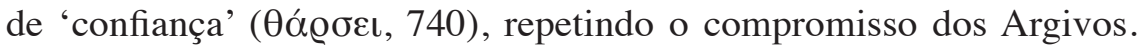

38 A estratégia poética é mais uma vez semelhante à de uma teichoskopia. É certo que não se trata de uma guerra, em que, de dentro das muralhas, se procura observar o inimigo lá fora; trata-se, no entanto, de uma perseguição, que é um conflito de natureza pessoal, em que o perigo se avista também à distância. A táctica narrativa, que inclui o contraste de planos, o toque cromático, a visibilidade progressiva, esses são traços comuns.

39 O próprio coro, aproximando os dois momentos de angústia, põe em dúvida o resultado da sua fuga anterior, sublinhando o contraste entre a atitude cénica que lhe cabe tomar nas duas situações. 
Do tremor íntimo que afecta a perseguida, a atenção das Danaides salta para o perseguidor; nos filhos de Egipto vê uma imagem de violência, de condutores insaciáveis de guerra. Também em tom lírico, como eco do seu próprio enunciado, as mulheres materializam o espírito bélico dos primos, nas naus 'robustas e negras', como 'negro' é também o enorme exército que, tomado de cólera, as tripula (743-745). A caracterização de estrangeiros que, no caso das mulheres, fora feita pela constatação imediata do seu exterior - cor da pele e vestes -, na dos Egípcios faz-se pela imaginação, mas são os mesmos - pele e trajos - os seus traços distintivos. De resto Dânao, renovando o mesmo confronto de raças que antes impressionara Pelasgo perante as Danaides, compara os sobrinhos com a gente do lugar, 'de braços polidos pelos ardores do meio-dia' (746-747).

$\mathrm{O}$ pensamento seguinte vai para o momento do encontro, aquele em que elas, vítimas indefesas, se confrontarão com o inimigo; à sobriedade de uma interrogação sobre a fraqueza feminina, contrapõe-se o aparato metafórico com que se valoriza a agressividade masculina; ímpios, violentos, pérfidos, eles assemelham-se a corvos destemidos que assaltam os altares (750-752). Por fim, é para a impiedade que vai o pensamento das mulheres; afirmativas quanto à indiferença que imaginam nos primos em relação à autoridade divina, é pela sua arrogância que os sobrepõem a cães sem vergonha, 'indiferentes à voz divina' (757-759).

A longa demora das manobras de desembarque, que Dânao descreve para justificar o lapso de tempo que se antecipa à vinda anunciada dos Egípcios (764-775), proporciona duas ocorrências de relevância dramática: a partida de Dânao em busca de socorro e a expectativa crescente que as Danaides vão agora expandir num canto. Afinal, numa peça de súplica, a entrada habilmente adiada do perseguidor será sempre um momento exuberante de teatro. As palavras pressupõem movimentos hesitantes e expressivos de uma angústia maior: para onde fugir (776-778). Porque o coro se encontra manietado pelo espaço da cena, a incapacidade de fugir estimula-lhe a imaginação. 'Sonha', por isso, com transformar-se em fumo negro ou poeira, para se sumir no ar (779-783); em encontrar asilo nas alturas do éter ou em algum lugar ermo e inóspito (792-799), no que são os tradicionais escapismos trágicos. Ou mesmo, num crescendo emotivo, subjacente à ambiguidade das palavras que pronuncia, a morte é algo que, como último refúgio, se lhe oferece.

Em vez de estimulante à fuga, o medo transforma-se em bloqueio e interioriza-se: é a alma que estremece, o coração que palpita (784-785), 
o terror que se torna mortal (786); o canto, em conformidade, sobe de tom, em brados que pretendem erguer-se ao céu, dirigidos à distância olímpica dos deuses (808-810). É de Zeus que se espera o arbítrio daquelas que são as partes em iminente confronto: frágeis, de um lado, as suplicantes; do outro a hybris dos filhos de Egipto, propulsionada pelo vigor masculino, à caça de uma presa que pretendem, pela força, render ao seu desejo.

O clímax do pavor (825) atinge-se com a presença efectiva do perseguidor, recebido pelas mulheres com gritos e a corrida para o altar, seu único refúgio, despojadas que estão dos seus defensores humanos, Dânao e Pelasgo. A prometida violência física vê chegado o seu momento. Em representação do inimigo ${ }^{40}$, o arauto egípcio introduz na cena a pressão da urgência. Que, prisioneiras, as mulheres se encaminhem para o barco a toda a pressa $(836-837,842,858-862,882-883)$. Chovem, da boca do arauto, as ameaças, de cabelos arrancados, corpos marcados a ferros, cabeças cortadas, sangue a jorrar em abundância (834-841, 884, 909-910); ameaças tanto mais pungentes quanto lhes cabe substituírem-se à realidade ou reforçá-la. Do egípcio vem também o registo da reacção feminina (872-876): gritos, gemidos, apelos aos deuses.

À resistência sucede-se a cedência. Reconhecendo como os altares parecem não interpor uma protecção eficiente, além de lhes manietarem os passos, é como aranhas (887), em movimentos lentos e resistentes que elas cedem, 'passo a passo', à imposição de um inimigo que vêem como um fantasma, negro, de pele e de alma (888). Indiferente aos deuses gregos que não respeita, o arauto dá largas a um procedimento bárbaro (914-915): avança com violência e arrebata, pelos vestidos, a sua presa. $\mathrm{O}$ coro rende-se, enfim, consumado num abatimento impotente todo um longo temor. Chegou ao termo o percurso doloroso das Danaides.

Uma nova fase na sua saga se inicia: a da sua inclusão em Argos que traz, ao seu destino, um momento de tranquilidade, mesmo se passageiro. Depois da intervenção de Pelasgo, é dado, uma vez mais, lugar à 'confiança' (0@óoos, 954) e chegada a hora de um movimento tranquilo a caminho dos muros da cidade, o que Taplin 1977: 239 define como 'um movimento

40 É discutido se o arauto faz a sua entrada sozinho, ou se vem acompanhado de um coro masculino de vários elementos, talvez até 50. Mas o texto não prova a presença deste segundo grupo. Taplin 1977: 216-217 reconhece que o texto pressupõe apenas ameaças e que não é necessário confrontar um só arauto com a necessidade de aprisionar todo o coro de mulheres. Mesmo assim admite que, dada a vulgaridade na tragédia de acompanhantes mudos, alguns figurantes podiam seguir o arauto. Sobre o assunto, vide supra nota 13. 
cénico coeso, digno e organizado, após a turbulência selvagem das cenas anteriores'. Enfim livres, as Danaides seguem as instruções paternas, de modo a que a sua presença na cidade seja bem aceite. É então em boa ordem (975-979) que se preparam para deixar a cena e ingressar, ainda que provisoriamente, num futuro de paz. Às terras do Nilo, relegadas ao passado, sobrepõe-se, na celebração dos seus cantos, a cidade dos Pelasgos (1024-1025), no que é a consumação do seu retorno às origens e o fechar de um primeiro ciclo mítico.

\section{Bibliografia:}

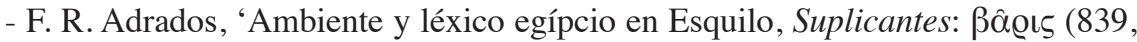

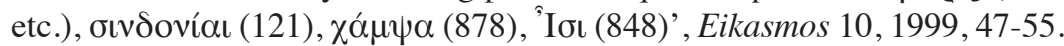

-R. S. Caldwell, 'The psychology of Aeschylus' Supplices', Arethusa 7. 1, 1974, 45-70.

-T. Gantz, 'Love and death in the Suppliants of Aeschylus', Phoenix 32, 1978, 279-287.

-A. F. Garvie, Aeschylus' Supplices: Play and trilogy, Cambridge, 1969.

-M. Griffith, Aeschylus. Prometheus Bound, Cambridge, 1983.

-E. Hall, Inventing the barbarian, Oxford, 1989.

-H. F. Johansen, E. W. Whittle, Aeschylus. The Suppliants. II, Nordisk Forlag, 1980.

-A. Kavoulaki, 'Choral self-awareness: on the introductory anapaests of Aeschylus' Supplices', in L. Athanassaki, E. Bowie (eds.), Archaic and classical choral song, Berlin / Boston, 2011.

-H. Lloyd-Jones, 'The Suppliants of Aeschylus', in E. Segal (ed.), Oxford Readings in Greek Tragedy, Oxford, reimpr. 1991.

-M. McCall, 'The secondary choruses in Aeschylus' Supplices', Classical Antiquity 9, 1976, 117-131.

-J. de Romilly, La crainte et l'angoisse dans le théâtre d'Eschyle, Paris, 1971.

-Th. G. Rosenmeyer, The art of Aeschylus, Berkeley, Los Angeles, London, 1982.

-O. Taplin, The stagecraft of Aeschylus, Oxford, 1977. 